\title{
Gene Therapy for XSCID: The First Success of Gene Therapy
}

\author{
A review of: Cavazzana-Calvo M, Hacein-Bey S, de Saint Basile G, Gross F, Yvon E, Nusbaum P, Selz F, Hue C, Certain S, \\ Casanova JL, Bousso P, Deist FL, Fischer A 2000 Gene Therapy of Human Severe Combined Immunodeficiency (SCID)-X1 \\ Disease. Science 288:669-672.
}

G ENE THERAPY IS an emerging medical modality in which genetic diseases will be corrected by transfer of a normal version of the relevant gene into a patient's somatic cells. Gene transfer into the hematopoietic stem cells (HSC) of patients with hemoglobinopathies, congenital immune deficiencies and lysosomal storage diseases followed by their autologous transplantation could provide the same benefits as allogeneic transplantation, without the immunologic complications of graft rejection, graft versus host disease, and post-transplantation immunosuppressive therapy. While the use of gene therapy to treat blood diseases is logical, this vision remains unfulfilled, primarily due to the inadequacies of the tools used for gene transfer and expression. Despite cycles of rising hope and sinking despair in the field of gene therapy, the techniques for gene transfer, gene expression, and hematopoietic stem cell manipulation have steadily improved.

There have been clinical trials of gene therapy since 1990. The first attempt to treat a disease targeted a form of severe combined immune deficiency (SCID) due to defects in the gene encoding adenosine deaminase (ADA). SCID was chosen because of evidence from three decades of experience with allogeneic bone marrow transplantation for SCID which demonstrated that a modest number of genetically normal bone marrow HSC can develop into a protective immune system (1).

The first trial of gene transfer for ADA-deficient SCID actually used peripheral blood $\mathrm{T}$ lymphocytes, rather than bone marrow (HSC). Prolonged survival of the gene-corrected T lymphocytes over nearly a decade has been documented (2). But, it is not possible to determine whether the patients had any clinical benefit as a result of the gene transfer, because they continue to be treated with enzyme replacement therapy, by weekly intramuscularly injections of a modified form of ADA

\section{Donald B. KoHn}

protein. Subsequent clinical trials of gene transfer for ADA-deficient SCID have produced modest results, (3), without incontrovertible evidence of clinical benefit.

A recent report by Cavazzana-Calvo et al. (4) validates the concept of SCID as a favorable model disease for early gene therapy studies and represent the first demonstration of a significant clinical benefit from gene therapy. Gene therapy for the X-linked form of SCID (XSCID) was attempted in two infants. XSCID is due to genetic defects of an X-linked gene encoding a component of the cell surface receptor for five different growth factors involved in lymphocyte development and activation, the common cytokine receptor gamma chain or $\gamma \mathrm{c}$.

Bone marrow was collected from the infants and exposed to a retroviral vector carrying a normal copy of the human $\gamma \mathrm{c}$ gene. The marrow cells were returned to the infants by intravenous infusion. Over the subsequent months, both infants developed normal numbers of $T$ lymphocytes and natural killer (NK) cells, which showed evidence of immunologic function. Both infants have remained in good health, free of opportunistic infections, growing and developing without protective isolation. Initial evidence suggests they have also developed B lymphocyte function with the presence of protective levels of antibodies, although the number of B lymphocytes remains low.

The tempo at which $\mathrm{T}$ lymphocyte numbers and function developed is essentially identical to the response to transplantation of genetically normal hematopoietic stem cells from the bone marrow of a healthy, HLA-matched sibling donor. There was near-normalization of $\mathrm{T}$ cell numbers within 2 to 3 months, which reflects the minimal time it takes for a human HSC or lymphoid progenitor to enter the thymus, undergo maturation and enter the periphery, based upon observation of SCID patients who receive $T$ cell depleted bone marrow transplant.

This is a landmark paper. It clearly represents the most significant physiologic response achieved in any clinical gene transfer study to date. While the duration of follow-up is still quite short (1 year) the findings meet all expectations for initial success in the treatment of this disorder.

Since the initial trials of gene therapy for ADA-deficient SCID, almost 400 clinical trials of gene therapy have been performed for a broad array of conditions (cancer, cardiovascular disease, AIDS, cystic fibrosis, Gaucher disease), involving more than 3,000 subjects. There have been only hints of potential efficacy in a few. Therefore, the study in XSCID provides, at last, proof of principle for gene therapy.

1. Parkman R 1986 The application of bone marrow transplantation to the treatment of genetic diseases. Science 232:1373-1378

2. Blaese RM, Culver KW, Miller AD, Carter CS, Fleisher T, Clerici M, Shearer G, Chang L, Chiang Y, Tolstochev P, Greenblatt JJ, Rosenberg SA, Klein H, Berger M, Mullen CA, Ramsey WJ, Muul L, Morgan RA, Anderson WF 1995 T lymphocytedirected gene therapy for ADA-SCID: initial trial results after 4 years. Science 270:475-480

3. Kohn DB, Hershfield MS, Carbonaro D, Shigeoka A, Brooks J, Smogorzewska EM, Barsky LW, Chan R, Burotto F, Annett G, Nolta JA, Crooks G, Kapoor N, Elder M, Wara D, Bowen T, Madsen E, Snyder FF, Bastian J, Muul L, Blaese RM, Weinberg K, Parkman R 1998 T lymphocytes with a normal ADA gene accumulate after transplantation of transduced autologous umbilical cord blood CD34+ cells in ADA-deficient SCID neonates. Nat Med 4:775-780

4. Cavazzana-Calvo M, Hacein-Bey S, de Saint Basile G, Gross F, Yvon E, Nusbaum P, Selz F, Hue C, Certain S, Casanova JL, Bousso P, Le Deist F, Fischer A 2000 Gene therapy of human severe combined immunodeficiency (SCID)-X1 disease. Science 288:669-672

Childrens Hospital Los Angeles

Division of Research Immunology/Bone Marrow Transplantation

Box \#62, 4650 Sunset Boulevard

Los Angeles, CA 90027, USA 